\title{
Injured trilobites within a collection of dinosaurs: Using the Royal Tyrrell Museum of Palaeontology to document Cambrian predation
}

\author{
Russell D. C. Bicknell and Brayden Holland
}

\begin{abstract}
Biomineralised exoskeletons of trilobites are ideal for recording abnormalities, documenting injuries from failed attacks, and understanding predation in the fossil record. The illustration of new injured Cambrian-aged trilobites is particularly important for elucidating aspects of early Paleozoic predator-prey systems and identifying groups that were targets of this early predation. We document six new abnormal trilobite specimens from the Royal Tyrrell Museum of Palaeontology, including the first evidence for injuries on the corynexochid trilobite Hemirhodon amplipyge. These new data highlight the importance of museum collections in uncovering unique and informative specimens for studies of predation on early animals.
\end{abstract}

Russell D. C. Bicknell. Palaeoscience Research Centre, School of Environmental and Rural Science, University of New England, Armidale, New South Wales, 2351, Australia. rdcbicknell@gmail.com Brayden Holland. Palaeoscience Research Centre, School of Environmental and Rural Science, University of New England, Armidale, New South Wales, 2351, Australia. blongle2@myune.edu.au

Keywords: Trilobites; abnormalities; Cambrian Explosion; durophagy; healed injuries; predation

Submission: 10 April 2020. Acceptance: 7 July 2020.

\section{INTRODUCTION}

Trilobites were an exceptionally diverse group of Paleozoic arthropods, with over 22,000 species, that are characterised primarily by their biomineralised dorsal exoskeletons; a feature that resulted in a high preservational protentional (Webster, 2007; Paterson, 2019). These exoskeletons also preserve an unprecedented record of abnormal features, which can be attributed to injuries, developmental aberrations, diseases, and parasites (Owen, 1985; Babcock, 1993, 2003, 2007; Bicknell and Paterson, 2018; Vinn, 2018; Bicknell and Pates, 2020). The Cambrian origin of trilobites, and presence of such specimens with abnormalities,

Bicknell, Russell D. C. and Holland, Brayden. 2020. Injured trilobites within a collection of dinosaurs: Using the Royal Tyrrell Museum of Palaeontology to document Cambrian predation. Palaeontologia Electronica, 23(2):a33. https://doi.org/10.26879/1087 palaeo-electronica.org/content/2020/3094-injured-trilobites-in-the-tmp 
have made the group central to understanding the rise of predation (Babcock and Robison, 1989; Babcock, 1993; Pates et al., 2017; Pates and Bicknell, 2019). Curiously, abnormalities on Cambrianaged trilobites have been documented more than any other time-period, which may reflect a higher intensity of research on injuries from this time period, a prevalence of material, and/or a true biological signal (Pates et al., 2017; Bicknell and Paterson, 2018). Regardless, new abnormal specimens provide key information for developing our knowledge of predation, moulting complications, and pathological developments (Owen, 1985; Bicknell and Pates, 2020). Under-explored museum collections are ideal for identifying important specimens, as they often house new examples of abnormal specimens, often from new localities (Bicknell and Pates, 2019, 2020). Museum collections have also been used to identify abnormality stereotypy (Babcock and Robison, 1989; Babcock, 1993).

Canada's rich fossil record has been on show at the Royal Tyrrell Museum of Palaeontology, Drumheller, Alberta (TMP) for over 30 years, and this has made the museum one of the central hubs of Canadian palaeontological research. This museum, and associated research output, is most famous for its extensive vertebrate collection, particularly the remains of Late Cretaceous dinosaurs from Alberta (e.g., Ryan and Evans, 2005; Eberth et al., 2013). As such, there are thousands of specimens housed at the TMP that have greatly increased knowledge of extinct vertebrates (Currie and Koppelhus, 2015). Despite the primary focus on dinosaur and other vertebrate groups, the TMP collection also houses an array of invertebrate taxa (Motz et al., 2001). To expand the use of this diverse collection, and to align with recent research documenting Cambrian predation (Fatka et al., 2015; Pates et al., 2017; Bicknell et al., 2018c; Bicknell and Pates, 2019; Klompmaker et al., 2019; Pates and Bicknell, 2019), Cambrian-aged fossils were reviewed for abnormal trilobite specimens. We present six new examples of abnormal trilobites, representing the taxa Gabriellus kierorum, Ogygopsis klotzi, Modocia typicalis, and the first record of an abnormal Hemirhodon amplipyge. This highlights the importance of mining museum collections to increase our knowledge of abnormal and predated animals throughout the Phanerozoic.

\section{MATERIALS AND METHODS}

Specimens from Cambrian-aged deposits within the TMP collection were reviewed for trilo- bites showing some form of abnormality; features identified by their aberrant morphology (see discussions in Owen, 1985; Bicknell et al., 2018c; Bicknell and Pates, 2019; and references therein). Within the $\sim 5500$ examined specimens, six abnormal individuals were identified. Specimens were photographed with a Canon EOS 5DS camera under LED light using a Canon MP-E $65 \mathrm{~mm} 1-5 \mathrm{x}$ macro lens and a Sigma 50mm f/1.4 DG HSM lens.

\section{RESULTS}

\section{Gabriellus kierorum Corbacho and López- Soriano, $2013 \quad$ TMP.1983.021.0034;} TMP.1983.021.0039, Atan Group; Rosella Formation? (Series 2, Stage 4), British Columbia, Canada (Figure 1).

Two Gabriellus kierorum specimens were identified with abnormalities. TMP.1983.021.0034 is preserved as a complete dorsal exoskeleton (82 $\mathrm{mm}$ long) with an abnormality in the centre of the left pleural lobe (Figure 1A, B). The pleurae of thoracic segments 5 and 6 are truncated by $\sim 15 \mathrm{~mm}$ relative to the other pleurae on the specimen. The pleurae on these segments are show minute tips, indicating a degree of regeneration (Pates et al., 2017).

TMP.1983.021.0039 is preserved as a complete dorsal exoskeleton ( $55 \mathrm{~mm}$ long) with abnormalities on the posterior sections of the left and right pleural lobes (Figure 1C). Pleural spines on the $7^{\text {th }}-9^{\text {th }}$ thoracic segments of the left pleural lobe are truncated. The $7^{\text {th }}$ and $8^{\text {th }}$ spines are truncated by $13 \mathrm{~mm}$ relative to undamaged spines, have rounded edges, and appear to be slightly cicatrised (white arrows, Figure 1D). The 9th segment shows some degree of spine recovery and is $\sim 50 \%$ the length of undamaged spines (black arrow, Figure 1B). On the right pleural lobe, the pleural spines on the $7^{\text {th }}$ and $8^{\text {th }}$ thoracic segments are truncated by $\sim 11 \mathrm{~mm}$ relative to other spines and partly fused together (Figure 1E). This has produced a ' $V$ '-shaped indentation. There is no evidence of cicatrisation or regrowth along the margin of this abnormality.

Ogygopsis klotzi (Rominger, 1887) TMP1983.142.0002; TMP1983.257.0001, Stephen Formation (Miaolingian Series, Wuliuan), British Columbia, Canada (Figure 2).

Two specimens of Ogygopsis klotzi with abnormalities were identified. Both specimens lack free cheeks and are therefore examples of axial shield moults (Daley and Drage, 2016; Drage et al., 2018; Drage, 2019). 

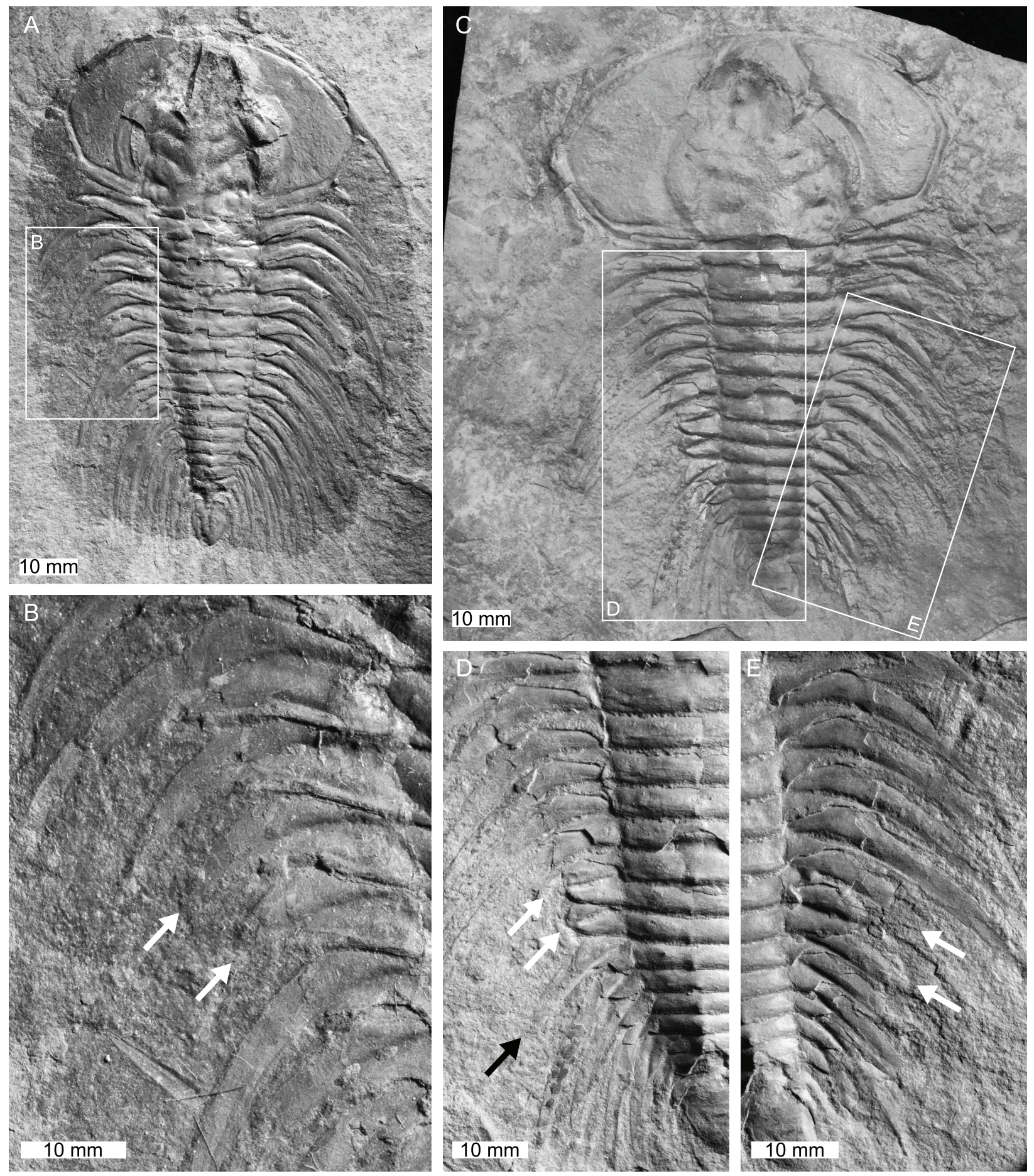

FIGURE 1. Gabriellus kierorum specimens from the (?)Rosella Formation. A, B. Gabriellus kierorum with truncation of left pleural spines on the fifth and sixth thoracic segment (TMP.1983.021.0034). A: Complete specimen. B: Close up of abnormality (white arrows). C-E: Gabriellus kierorum with bilaterally expressed thoracic abnormalities (TMP.1983.021.0039). C: Complete specimen. D: Close up of abnormality on the left side of the specimen (white arrows) and the partly recovered spine (black arrow). E: Close up of abnormality on the right side of the specimen (white arrows). 

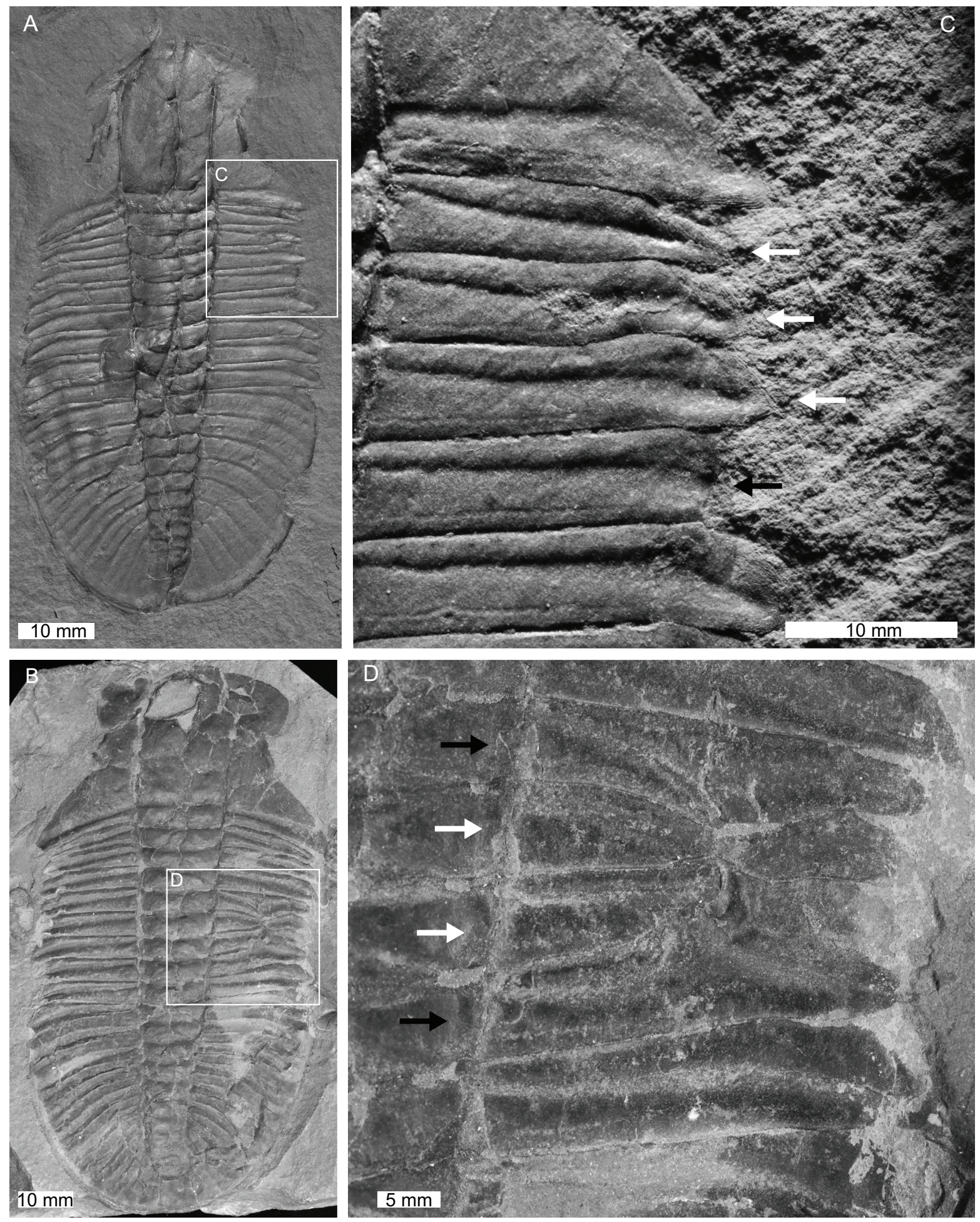

FIGURE 2. Ogygopsis klotzi specimens from the Stephen Formation with thoracic abnormalities. A, C: Ogygopsis klotzi showing truncation of the first four pleural spines of the right thoracic pleural lobe (TMP.1983.142.0002). A: Complete specimen. C: Close up of truncation of the right pleural spines. Note the ' $L$ '-shaped injury formed by 1 st $3^{\text {rd }}$ thoracic segments (white arrows), and the more notable truncation of the $4^{\text {th }}$ segment (black arrow). B, D: Ogygopsis klotzi with an abnormality on the right pleural lobe that impacts the $4^{\text {th }}-7^{\text {th }}$ pleural spines (TMP. 1983.257.0001). B: Complete specimen. D: Close up of abnormality on the right pleural spines, showing pinching of the $5^{\text {th }}$ and $6^{\text {th }}$ segments (white arrows) and warping of the $4^{\text {th }}$ and $7^{\text {th }}$ segments (black arrows). 

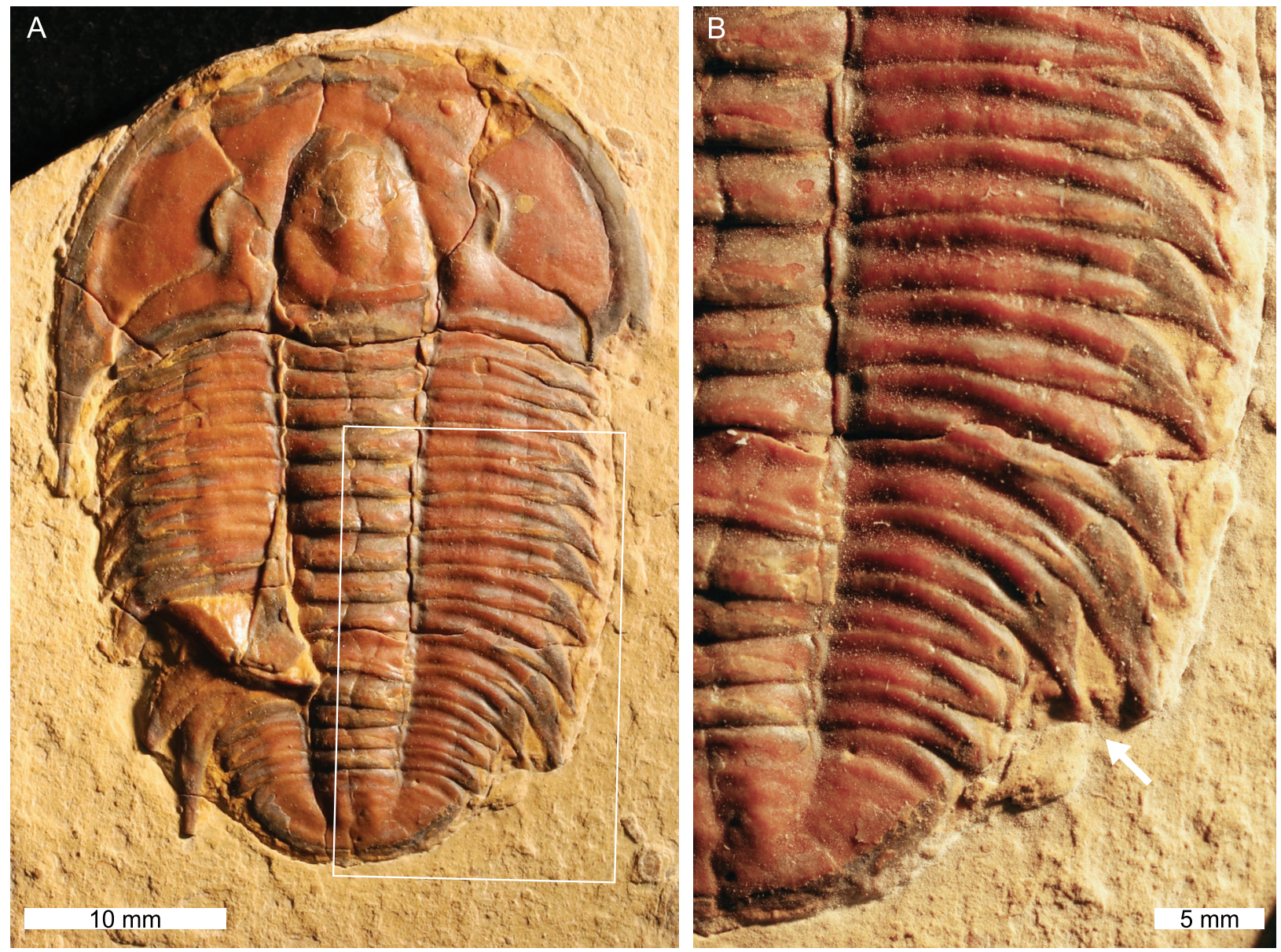

FIGURE 3. Modocia typicalis specimen with an abnormality on the right $11^{\text {th }}$ thoracic segment (TMP1984.50.0004). A: Complete specimen. B: Close up of the truncated pleural spine on the right $11^{\text {th }}$ thoracic segment (white arrow).

TMP1983.142.0002 is $73 \mathrm{~mm}$ long with an abnormality on the anterior section of the right pleural lobe (Figure 2A). The pleurae of thoracic segments $1-4$ are truncated by $2 \mathrm{~mm}$ relative to other segments (Figure 2C). Segments 1-3 form an 'L'-shaped injury that shows limited thoracic recovery (these segments are $\sim 75 \%$ the length of undamaged sections) and does not show evidence of cicatrisation. Further, the $4^{\text {th }}$ segment is more truncated than segments 1-3 $(2.5 \mathrm{~mm})$. The margin of this abnormality is not obviously cicatrised. The degree of indentation suggests that this abnormality likely occurred more recently than the more anterior segments.

TMP1983.257.0001 is $101 \mathrm{~mm}$ long and has an abnormality on the centre of the right pleural lobe that affects thoracic segments 4-7 (Figure 2B). Segments 5 and 6 are pinched together and segments 4 and 7 are warped about this point (Figure 2D). There is no evidence of cicatrisation along the margin of this abnormality.
Modocia typicalis (Resser, 1938), TMP 1984.50.0004. Wheeler Formation (Miaolingian Series, Drumian), Utah, USA (Figure 3).

TMP 1984.50.0004 is preserved as a complete dorsal exoskeleton (40 mm long) with an abnormality on the posterior part of the right pleural lobe. The hypertrophied pleural spine on the $11^{\text {th }}$ thoracic segment is truncated by $4 \mathrm{~mm}$ relative to the same spine on the left side. This truncation forms a single segment injury ( $\mathrm{SSI}$, sensu Bicknell and Pates, 2020) that is slightly rounded and shows evidence of cicatrisation along the margin.

Hemirhodon amplipyge Robison, 1964; TMP.2006.036.0102. Duchesnay Member, Chancellor Formation (Miaolingian Series, Drumian); British Columbia, Canada (Figure 4).

TMP.2006.036.0102 is preserved as a complete dorsal exoskeleton (87 mm long) with an abnormality on the anterior section of the left side of the pygidium. The abnormality truncates the pygidial margin by $3.9 \mathrm{~mm}$. The abnormality is 

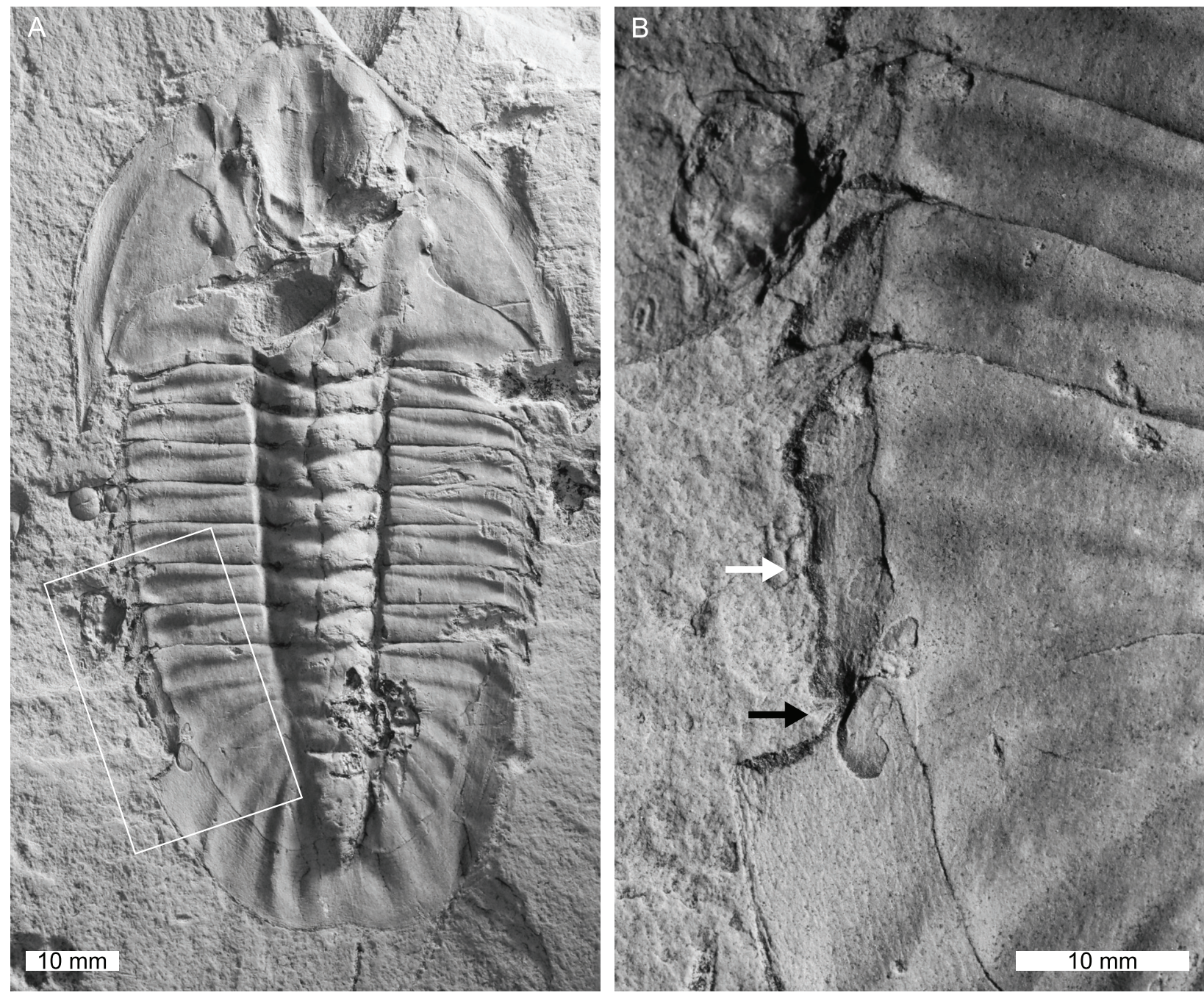

FIGURE 4. The first record of a Hemirhodon amplipyge specimen with an abnormality (TMP.2006.036.0102). A: Complete specimen. B: Close up of the abnormality on left side of pygidium, showing a truncated 'W'- (white arrows) and 'V'-shape (black arrow) on pygidial margin.

expressed as a shallow "W"-shape indentation next to a more posterior, deeper, and acuate "V"-shape (white and black arrows, respectively, in Figure $4 \mathrm{~B})$. The margin of the abnormality is cicatrised.

\section{DISCUSSION}

The abnormalities considered here are morphologically similar to examples that have been attributed to injuries (Šnajdr, 1978; Owen, 1985; Bicknell and Paterson, 2018; Bicknell and Pates, 2020). These abnormal specimens are therefore interpreted either as individuals that experienced failed predation, or individuals who injured themselves as a result of a moulting complication or other behaviour (Owen, 1985). The cicatrised abnormality observed on the Ogygopsis klotzi specimen TMP1983.142.0002 (Figure 2A, C) is morphologically similar other $O$. klotzi injuries that were attributed to failed attacks (Table 1). Further, the 'W'-shaped morphology and cicatrisation of the injury to the Hemirhodon amplipyge specimen is comparable to other injuries, suggestive of at least one failed attack (Figure 4). One of the most curious specimens examined here is the Ogygopsis klotzi specimen TMP1983.257.0001 (Figure 2B, D) that has warped thoracic segments; an abnormality previously unknown in this group, but has been reported in other trilobite taxa (Šnajdr, 1955). The disruption of these segments may reflect an injury from moulting, deformation during a soft-shelled stage, or potentially a developmental issue. It seems unlikely that $O$. klotzi experienced complications from moulting as the taxon lacks large pleural spines (Conway Morris and Jenkins, 1985). We therefore suggest that the individual either experi- 
TABLE 1. Examples of previously documented abnormal Ogygopsis klotzi and the suggested predator groups.

\begin{tabular}{|c|c|c|}
\hline Morphology of injury & Proposed predator & Publication \\
\hline $\begin{array}{l}\text { 'U'-shaped injury on right side of thorax } \\
\text { impacting thoracic segments } 3-6\end{array}$ & Possibly Anomalocaris & Rudkin (1979, fig. 1A, B) \\
\hline $\begin{array}{l}\text { 'W'-shaped injury on left side of thorax } \\
\text { impacting thoracic segments } 6-8\end{array}$ & Possibly Anomalocaris & Rudkin $(1979$, fig. 1C, D) \\
\hline $\begin{array}{l}\text { 'W'-shaped injury on the anterior section of } \\
\text { the right side of pygidium }\end{array}$ & Possibly Anomalocaris & Rudkin (1979, fig. 1E, F) \\
\hline $\begin{array}{l}\text { 'V'-shaped injury on right side of thorax } \\
\text { impacting thoracic segments } 7-8\end{array}$ & Possibly Anomalocaris & $\begin{array}{l}\text { Rudkin (1979, fig. 1G, H), refigured in } \\
\text { Rudkin (2009, fig. 1B) }\end{array}$ \\
\hline $\begin{array}{l}\text { ' } U \text { '-shaped injury on posterior right side of } \\
\text { thorax impacting thoracic segment } 10 \text { and } \\
\text { the anterior right pygidium }\end{array}$ & Anomalocaris & Briggs and Whittington (1985, p. 37) \\
\hline $\begin{array}{l}\text { Cicatrized 'W'-shaped injury on the anterior } \\
\text { right side of pygidium }\end{array}$ & Anomalocaris sp. & Pratt (1998, fig. 1A) \\
\hline $\begin{array}{l}\text { 'W'-shaped injury on the right side of thorax } \\
\text { impacting thoracic segments } 3-6 \text { and minor } \\
\text { 'U'-shaped injury on the left side of the thorax } \\
\text { impacting thoracic section } 5\end{array}$ & Anomalocaris sp. & Nedin (1999, fig. 2C) \\
\hline $\begin{array}{l}\text { 'W'-shaped injury on the left side of thorax } \\
\text { impacting thoracic segments } 2-5\end{array}$ & $\begin{array}{l}\text { Total group euarthropod with gnathobases } \\
\text { or gnathobase-like structures; e.g. } \\
\text { amplectobeluid radiodonts, trilobites, and } \\
\text { other artiopodans }\end{array}$ & Bicknell and Pates (2020; fig. 7A, B) \\
\hline
\end{tabular}

enced an injury during a soft-shelled stage that deformed the exoskeleton, or the exoskeleton developed incorrectly.

Evidence for predators that targeted trilobites reiterates the question that has been considered since at least Öpik (1961), Alpert and Moore (1975), and Rudkin (1979): what was predating on Cambrian trilobites? The most likely predators are those trilobites and predatory artiopodans that displayed reinforced gnathobasic spines on protopodal sections of the walking legs, ideal for durophagy, similar to the extant horseshoe crabs (Bruton, 1981; Conway Morris and Jenkins, 1985; Zacaï et al., 2016; Bicknell et al., 2018a, b, 2019; Holmes et al., 2020). Radiodont groups, such as anomalocaridids, may have been capable of attacking those trilobites in a non-biomineralised state using fortified frontal appendages to grab and break prey, perhaps in conjunction with the radial mouthpart (Nedin, 1999; Daley et al., 2013; Bicknell and Paterson, 2018). However, doubt has been cast on shell-crushing ability of mouthparts (Whittington and Briggs, 1985; Hagadorn, 2009; Hagadorn et al., 2010; Daley and Bergström, 2012). Recent studies of other radiodont groups has highlighted the presence of taxa with gnathobasic-like structures on frontal appendages, which may have also been in used in predation (Cong et al., 2017, 2018). While such morphologies are not known from North American deposits, related taxa are known from the Stage 4 Kinzers Formation and Latham Shale (USA), Wuliuan Burgess Shale (Canada), and Drumian Wheeler Formation (Daley and Budd, 2010; Pates and Daley, 2019; Pates et al., 2019; Lerosey-Aubril et al., 2020). Finally, the raptorial frontal appendages of stem chelicerate Yohoia tenuis Walcott, 1912, may have functioned like a hammer and been capable of breaking biomineralised exoskeletons, in a manner comparable to stomatopods (Pratt, 1998; Haug et al., 2012; Bicknell and Paterson, 2018).

\section{CONCLUSIONS}

Examination of palaeontological collections that focus primarily on one part of the tree of life often permits the identification of novel palaeoecological data. The Royal Tyrrell Museum of Palaeontology represents a particularly interesting example of this situation; although the museum focuses chiefly on vertebrate research, there is an expansive collection of invertebrate material. We have shown here that examining the arthropod section of the collection has uncovered previously unknown information on Cambrian trilobites. Another part of the invertebrate collection that would undoubtedly lend itself to key research is the molluscan material. Examining this section of the TMP would uncover new trends in predator-prey interactions involving this group across the Meso- 
zoic and could potentially be extended to consider further Palaeozoic palaeoecological systems.

\section{ACKNOWLEDGEMENTS}

This research was supported by funding from a Australian Research Council Discovery Project (DP200102005), UNE Postdoctoral Research Fellowship (to RDCB) and a Research Training Program Scholarship (to $\mathrm{BH}$ ). We thank Brandon Strilisky for access to the TMP collection, James
Gardner, and Rebecca Sanchez for help with the TMP collection, and the Royal Tyrrell Museum Cooperating Society for supporting the visitation. We thank Bruce Lieberman for clarifying the taxonomic placement of Gabriellus kierorum. We also thank Stephen Pates for his comments on an earlier draft that thoroughly improved the text. Finally, we thank the James D. Holmes and an anonymous referee for their insightful comments that improved the flow and focus of the text.

\section{REFERENCES}

Alpert, S.P. and Moore, J.N. 1975. Lower Cambrian trace fossil evidence for predation on trilobites. Lethaia, 8:223-230. https://doi.org/10.1111/j.1502-3931.1975.tb00926.x

Babcock, L.E. 1993. Trilobite malformations and the fossil record of behavioral asymmetry. Journal of Paleontology, 67:217-229. https://doi.org/10.1017/s0022336000032145

Babcock, L.E. 2003. Trilobites in Paleozoic predator-prey systems, and their role in reorganization of early Paleozoic ecosystems, p. 55-92. In Kelley, P., Kowalewski, M., and Hansen, T.A. (eds.), Predator-Prey Interactions in the Fossil Record. Springer, New York.

Babcock, L.E. 2007. Role of malformations in elucidating trilobite paleobiology: a historical synthesis, p. 3-19. In Mikulic, D.G., Landing, E., and Kluessendorf, J. (eds.), Fabulous Fossils-300 Years of Worldwide Research on Trilobites. University of the State of New York, State Education Dept., New York State Museum, New York.

Babcock, L.E. and Robison, R.A. 1989. Preferences of Palaeozoic predators. Nature, 337:695696. https://doi.org/10.1038/337695c0

Bicknell, R.D.C., Brougham, T., Charbonnier, S., Sautereau, F., Hitij, T., and Campione, N.E. 2019. On the appendicular anatomy of the xiphosurid Tachypleus syriacus and the evolution of fossil horseshoe crab appendages. The Science of Nature, 106:38. https://doi.org/ 10.1007/s00114-019-1629-6

Bicknell, R.D.C. and Paterson, J.R. 2018. Reappraising the early evidence of durophagy and drilling predation in the fossil record: implications for escalation and the Cambrian Explosion. Biological Reviews, 93:754-784. https://doi.org/10.1111/brv.12365

Bicknell, R.D.C. and Pates, S. 2019. Abnormal extant xiphosurids in the Yale Peabody Museum Invertebrate Zoology collection. Bulletin of the Peabody Museum of Natural History, 60:4153. https://doi.org/10.3374/014.060.0102

Bicknell, R.D.C. and Pates, S. 2020. Exploring abnormal Cambrian-aged trilobites in the Smithsonian collection. PeerJ, 8:e8453. https://doi.org/10.7717/peerj.8453

Bicknell, R.D.C., Ledogar, J.A., Wroe, S., Gutzler, B.C., Watson III, W.H., and Paterson, J.R. 2018a. Computational biomechanical analyses demonstrate similar shell-crushing abilities in modern and ancient arthropods. Proceedings of the Royal Society B: Biological Sciences, 285:20181935. https://doi.org/10.1098/rspb.2018.1935

Bicknell, R.D.C., Paterson, J.R., Caron, J.-B., and Skovsted, C.B. 2018b. The gnathobasic spine microstructure of Recent and Silurian chelicerates and the Cambrian artiopodan Sidneyia: Functional and evolutionary implications. Arthropod Structure \& Development, 47:12-24. https://doi.org/10.1016/j.asd.2017.12.001

Bicknell, R.D.C., Pates, S., and Botton, M.L. 2018c. Abnormal xiphosurids, with possible application to Cambrian trilobites. Palaeontologia Electronica, 21.2.19A:1-17. https://doi.org/ $10.26879 / 866$

Briggs, D.E.G. and Whittington, H.B. 1985. Terror of the trilobites. Natural History, 94:34-39.

Bruton, D.L. 1981. The arthropod Sidneyia inexpectans, Middle Cambrian, Burgess Shale, British Columbia. Philosophical Transactions of the Royal Society of London. Series B, Biological Sciences, 295:619-656. https://doi.org/10.1098/rstb.1981.0164 
Cong, P., Daley, A.C., Edgecombe, G.D., and Hou, X. 2017. The functional head of the Cambrian radiodontan (stem-group Euarthropoda) Amplectobelua symbrachiata. BMC Evolutionary Biology, 17:208. https://doi.org/10.1186/s12862-017-1049-1

Cong, P., Edgecombe, G.D., Daley, A.C., Pates, S., and Hou, X. 2018. New radiodontans with gnathobase-like structures from the Cambrian Chengjiang Biota and implications for the systematics of Radiodonta. Papers in Palaeontology, 4:605-621. https://doi.org/10.1002/ spp2.1219

Conway Morris, S. and Jenkins, R.J.F. 1985. Healed injuries in early Cambrian trilobites from South Australia. Alcheringa, 9:167-177. https://doi.org/10.1080/03115518508618965

Corbacho, J. and López-Soriano, F.J. 2013. Gabriellus kierorum: A new species of Judomiidae from the lower Cambrian (Series 2) of Canada. Batalleria, 19:13-19.

Currie, P.J. and Koppelhus, E.B. 2015. The significance of the theropod collections of the Royal Tyrrell Museum of Palaeontology to our understanding of Late Cretaceous theropod diversity. Canadian Journal of Earth Sciences, 52:620-629. https://doi.org/10.1139/cjes-2014-0173

Daley, A.C. and Bergström, J. 2012. The oral cone of Anomalocaris is not a classic "peytoia". Naturwissenschaften, 99:501-504. https://doi.org/10.1007/s00114-012-0910-8

Daley, A.C. and Budd, G.E. 2010. New anomalocaridid appendages from the Burgess Shale, Canada. Palaeontology, 53:721-738. https://doi.org/10.1111/j.1475-4983.2010.00955.x

Daley, A.C. and Drage, H.B. 2016. The fossil record of ecdysis, and trends in the moulting behaviour of trilobites. Arthropod Structure \& Development, 45:71-96. https://doi.org/ 10.1016/j.asd.2015.09.004

Daley, A.C., Paterson, J.R., Edgecombe, G.D., García-Bellido, D.C., and Jago, J.B. 2013. New anatomical information on Anomalocaris from the Cambrian Emu Bay Shale of South Australia and a reassessment of its inferred predatory habits. Palaeontology, 56:971-990. https://doi.org/10.1111/pala.12029

Drage, H.B. 2019. Quantifying intra-and interspecific variability in trilobite moulting behaviour across the Palaeozoic. Palaeontologia Electronica, 22.2.34:1-39. https://doi.org/10.26879/ 940

Drage, H.B., Holmes, J.D., García-Bellido, D.C., and Daley, A.C. 2018. An exceptional record of Cambrian trilobite moulting behaviour preserved in the Emu Bay Shale, South Australia. Lethaia, 51:473-492. https://doi.org/10.1111/let.12266

Eberth, D.A., Evans, D.C., Brinkman, D.B., Therrien, F., Tanke, D.H., and Russell, L.S. 2013. Dinosaur biostratigraphy of the Edmonton Group (Upper Cretaceous), Alberta, Canada: evidence for climate influence. Canadian Journal of Earth Sciences, 50:701-726. https:// doi.org/10.1139/cjes-2012-0185

Fatka, O., Budil, P., and Grigar, L. 2015. A unique case of healed injury in a Cambrian trilobite. Annales de Paléontologie, 101:295-299. https://doi.org/10.1016/j.annpal.2015.10.001

Hagadorn, J.W. 2009. Taking a bite out of Anomalocaris. Walcott 2009 International Conference on the Cambrian Explosion, pp. 33-34.

Hagadorn, J.W., Schottenfeld, M.T., and McGowan, D. 2010. Putting Anomalocaris on a softfood diet? Geological Society of America Abstracts, 42:320.

Haug, J.T., Waloszek, D., Maas, A., Liu, Y., and Haug, C. 2012. Functional morphology, ontogeny and evolution of mantis shrimp-like predators in the Cambrian. Palaeontology, 55:369-399. https://doi.org/10.1111/j.1475-4983.2011.01124.x

Holmes, J.D., Paterson, J.R., and García-Bellido, D.C. 2020. The trilobite Redlichia from the lower Cambrian Emu Bay Shale Konservat-Lagerstätte of South Australia: systematics, ontogeny and soft-part anatomy. Journal of Systematic Palaeontology, 18:295-334. https:// doi.org/10.1080/14772019.2019.1605411

Klompmaker, A.A., Kelley, P.H., Chattopadhyay, D., Clements, J.C., Huntley, J.W., and Kowalewski, M. 2019. Predation in the marine fossil record: Studies, data, recognition, environmental factors, and behavior. Earth-Science Reviews, 194:472-520. https://doi.org/ 10.1016/j.earscirev.2019.02.020

Lerosey-Aubril, R., Kimmig, J., Pates, S., Skabelund, J., Weug, A., and Ortega-Hernández, J. 2020. New exceptionally-preserved panarthropods from the Drumian Wheeler KonservatLagerstätte of the House Range of Utah. Papers in Palaeontology. https://doi.org/10.1002/ spp2.1307 
Motz, K.J., Johnston, P.A., Collom, C.J., and Krause, F.F. 2001. New Burgess Shale-like biotas from the Upper Middle Cambrian Duchesnay unit (Chancellor Group) at Haiduk Peak and Miller Pass, British Columbia. Canadian Paleontological Conference, London, Ontario, Program with Abstracts, pp. 33-37.

Nedin, C. 1999. Anomalocaris predation on nonmineralized and mineralized trilobites. Geology, 27:987-990. https://doi.org/10.1130/0091-7613(1999)027\%3C0987:aponam\%3E2.3.co;2

Öpik, A.A. 1961. The geology and palaeontology of the headwaters of the Burke River, Queensland 53. Bureau of Mineral Resources, Geology and Geophysics, Commonwealth of Australia.

Owen, A.W. 1985. Trilobite abnormalities. Transactions of the Royal Society of Edinburgh: Earth Sciences, 76:255-272. https://doi.org/10.1017/s0263593300010488

Paterson, J.R. 2020. The trouble with trilobites: classification, phylogeny and the cryptogenesis problem. Geological Magazine, 157:35-46. https://doi.org/10.1017/S0016756819000426

Pates, S. and Bicknell, R.D.C. 2019. Elongated thoracic spines as potential predatory deterrents in olenelline trilobites from the lower Cambrian of Nevada. Palaeogeography, Palaeoclimatology, Palaeoecology, 519:295-306. https://doi.org/10.1016/ j.palaeo.2018.12.013

Pates, S. and Daley, A.C. 2019. The Kinzers Formation (Pennsylvania, USA): the most diverse assemblage of Cambrian Stage 4 radiodonts. Geological Magazine, 156:1233-1246. https:// doi.org/10.1017/s0016756818000547

Pates, S., Bicknell, R.D.C., Daley, A.C., and Zamora, S. 2017. Quantitative analysis of repaired and unrepaired damage to trilobites from the Cambrian (Stage 4, Drumian) Iberian Chains, NE Spain. Palaios, 32:750-761. https://doi.org/10.2110/palo.2017.055

Pates, S., Daley, A.C., Edgecombe, G.D., Cong, P., and Lieberman, B.S. 2019. Systematics, preservation and biogeography of radiodonts from the southern Great Basin, USA, during the upper Dyeran (Cambrian Series 2, Stage 4). Papers in Palaeontology. https://doi.org/ 10.1002/spp2.1277

Pratt, B.R. 1998. Probable predation on Upper Cambrian trilobites and its relevance for the extinction of soft-bodied Burgess Shale-type animals. Lethaia, 31:73-88. https://doi.org/ 10.1111/j.1502-3931.1998.tb00493.x

Resser, C.E. 1938. Cambrian System (restricted) of the southern Appalachians. Geological Society of America Special Papers, 15:1-139. https://doi.org/10.1130/spe15

Robison, R.A. 1964. Late middle Cambrian faunas from western Utah. Journal of Paleontology, 38:510-566.

Rudkin, D.M. 1979. Healed injuries in Ogygopsis klotzi (Trilobita) from the Middle Cambrian of British Columbia. Royal Ontario Museum, Life Sciences Occasional Paper, 32:1-8.

Rudkin, D.M. 2009. The Mount Stephen Trilobite Beds, p. 90-102. In Caron, J.-B.R. and Rudkin, D.M. (eds.), A Burgess Shale Primer-History, Geology, and Research Highlights. The Burgess Shale Consortium, Toronto.

Ryan, M.J. and Evans, D.C. 2005. Ornithischian Dinosaurs, p. 312-348. In Currie, P.J. and Koppelhus, E.B. (eds.), Dinosaur Provincial Park: a Spectacular Ancient Ecosystem Revealed. Indiana University Press, Bloomington, Indiana.

Šnajdr, M. 1955. Trilobiti drabovských a letenských vrstev českého ordoviku. Sborník Ústředního ústavu geologického, 22:1-57.

Šnajdr, M. 1978. Anomalous carapaces of Bohemian paradoxid trilobites. Sborník Geologických Věd Paleontologie, 20:7-31.

Vinn, O. 2018. Traces of predation in the Cambrian. Historical Biology, 30:1043-1049. https:// doi.org/10.1080/08912963.2017.1329305

Walcott, C.D. 1911. Cambrian geology and paleontology, II. Middle Cambrian Merostomata Smithsonian Miscellaneous Collections, 57:17-40

Walcott, C.D. 1912. Cambrian geology and paleontology. II. Middle Cambrian Branchiopoda, Malacostraca, Trilobita and Merostomata. Smithsonian Miscellaneous Collections, 57:145228.

Webster, M. 2007. A Cambrian peak in morphological variation within trilobite species. Science, 317:499-502. https://doi.org/10.1126/science.1142964

Whittington, H.B. and Briggs, D.E.G. 1985. The largest Cambrian animal, Anomalocaris, Burgess Shale, British Columbia. Philosophical Transactions of the Royal Society of London. B, Biological Sciences, 309:569-609. https://doi.org/10.1098/rstb.1985.0096 
Zacaï, A., Vannier, J., and Lerosey-Aubril, R. 2016. Reconstructing the diet of a 505-million-yearold arthropod: Sidneyia inexpectans from the Burgess Shale fauna. Arthropod Structure \&

Development, 45:200-220. https://doi.org/10.1016/j.asd.2015.09.003 